DOI: $10.4274 /$ tpa.45.242

\title{
Gelişmekte olan ülkelerde önemli bir sorun: annede ve yenidoğanda B12 vitamini eksikliği
}

\section{An important problem in developing countries: maternal and neonatal vitamin B12 deficiency}

\author{
Hasan Önal, Erdal Adal, Taliha Öner, Zerrin Önal, Ahmet Aydın* \\ Sağılı Bakanlığı, Bakırköy Kadın Doğum ve Çocuk Hastalıkları Eğitim ve Araştırma Hastanesi, Çocuk Metabolizma ve Endokrin Ünitesi, İstanbul, Türkive \\ *istanbul Üniversitesi Cerrahpaşa Tıp Fakültesi, Çocuk Sağlığı ve Hastalıkları Anabilim Dalı, Çocuk Metabolizma Bilim Dalı, İstanbul, Türkiye
}

\section{Özet}

Amaç: Son yıllarda yaşamın ilk altı aylık dönemi içinde nörolojik bulgular ile hastanemize başvuran ve B12 eksikliği tanısı alan olgularda ciddi bir artış dikkat çekmiştir. Bundan dolayı hastanemizde doğan bebeklerde annede ve bebekte B12 eksikliğinin araştııılması gereği duyulmuştur.

Gereç ve Yöntem: Çalıșma grubu hastanemizde doğum yapan 250 anne ve doğum sonrası 48 saatini doldurmuș term bebeklerden olușturuldu. Annede B12, bebekte B12 ve homosistein düzeyi ölçüldü. Hiperhomosisteinemisi bulunan olgularda B12 yetersizliği ile kobalamin sentez bozukluğu ayııcı tanısı yapıldı. B12 eksikliği tanısının konulmasında annede B12 eşik değeri 300 pg/ml, bebekte 200 pg/ml olarak alındı.

Bulgular: Annelerin \%81,6'sında bebeklerin \%42'sinde B12 yetersizliği saptandı. B12 eksikliği bulunan olguların ortalama homosistein düzeyi B12 düzeyi normal olan olgulara göre anlamlı olarak yüksek bulundu. Kobalamin sentez bozukluğu hiçbir olguda saptanmadı.

Çıkarımlar: Sosyoekonomik seviyenin düşük olması nedeni ile hayvansal proteinlerin anneler tarafından yeterince tüketilememesi, hem anne hem de bebek için B12 vitamin eksikliği açısından önemli bir neden olarak gözükmektedir. Bu çalıșma bizim gibi gelişmekte olan ülkelerde gebelik döneminde B12 desteğinin kas içine uygulanarak karşılanması gerekliliğini tartışmaya açmaktadır. (Türk Ped Arş 2010; 45: 242-5)

Anahtar sözcükler: Annede vitamin B12 eksikliği, bebekte vitamin B12 eksikliği, gelişmekte olan ülkeler

\section{Summary}

Aim: A significant increase has been noted in the number of infants admitted to our hospital due to neurologic findings and diagnosed as vitamin B12 deficiency within the first 6 months of life. Therefore, the aim of the present study was to determine the presence of maternal and neonatal vitamin B12 deficiency in infants born in our hospital.

Material and Method: The study population consisted of 250 women giving birth in our hospital and term newborns completing 48 hours after birth. Serum vitamin B12 levels were measured in mothers and vitamin B12 and homocysteine levels were measured in their newborns. The differential diagnosis between vitamin B12 deficiency and impaired cobalamin synthesis was made in infants with hyperhomocysteinemia. The diagnostic threshold for vitamin B12 deficiency was $300 \mathrm{pg} / \mathrm{mL}$ in mothers and $200 \mathrm{pg} / \mathrm{mL}$ in newborns.

Results: Vitamin B12 deficiency was found in $81.6 \%$ of the mothers and $42 \%$ of the infants. The mean homocysteine level in infants with vitamin B12 deficiency was significantly higher compared to those with normal vitamin B12 levels. Impaired cobalamin synthesis was not observed in any cases.

Conclusions: Inadequate consumption of animal proteins during pregnancy due to low socioeconomic status appears to be a significant risk factor for vitamin B12 deficiency both in the mother and the infant. The present study draws attention to the need for parenteral vitamin B12 replacement during pregnancy in developing countries, such as Turkey. (Turk Arch Ped 2010; 45: 242-5)

Key words: Developing countries, maternal vitamin B12 deficiency, neonatal vitamin B12 deficiency

\section{Giriş}

Yenidoğan döneminde B12 eksikliği nadirdir. B12 vitamin gebelik sırasında anneden bebeğe plasenta yolu ile aktif olarak geçer. Bebek 25-50 mcg B12 vitamini depo- su ile doğar. Büyüme için gerekli olan miktar 0,1 $\mathrm{mcg} / g u ̈ n ' d u ̈ r$. Yenidoğanın sahip olduğu bu depo ona 6 ay-1 yıl süreyle yeter. B12 vitamini DNA sentezi, metillenme, nörotrasmiter sentezi gibi görevlere sahip, homosistein/metyonin döngüsünde de görev alan bir kofaktördür.

Yazıșma Adresi/Address for Correspondence: Dr. Hasan Önal, Kınalıtepe Sok. Simitaș 7. Blok No: 61, Merter, İstanbul, Türkiye E-mail: hasanonal@hotmail.com Geliş Tarihi/Received: 08.09.2009 Tarihi/Accepted: 15.06.2010 
Bu nedenle, yenidoğan ve süt çocukluğu gibi büyümenin hızlı olduğu dönemlerde B12 vitamin eksikliği, diğer dönemlerde görülen anemi bulgusundan çok daha önemli nörolojik belirtilere yol açmaktadır. B12 vitamini deposu yetersiz olan çocukların, doğumu izleyen ilk bir aydaki gelişimleri normaldir. Bunların \%70'inde klinik bulgular 3-6 ay arasında ortaya çıkar. En sık yakınmaları letarji, hipotoni ve konvülziyondur. Bazen koma tablosu görülebilir. Tedaviyi izleyen ilk 3-4 ayda nörolojik bulgular düzelebilir, devam edebilir veya önceki nörolojik bulgular kötüleșebilir. Hastalarda beyin atrofisi veya hipoplazisi görülebilir. Olguların bir çoğunda miyelinizasyon tedaviden $12-13$ ay sonra tamamlanmaktadı; fakat kraniyal manyetik rezonans (MR) ile demiyelinizasyon bulgularının üç yıla kadar devam edebildiği gösterilmiştir. Erken tanı ve tedavi önemlidir $(1,2)$.

Bu çalışma ile hastanemizde doğan bebeklerin anne kaynaklı vitamin B12 eksikliği incelenmiştir.

\section{Gereç ve Yöntem}

Bu çalışma, Eylül-Ekim 2007 tarihleri arasında Sağlık Bakanlığı Bakırköy Kadın Doğum ve Çocuk Hastalıkları Eğitim ve Araştırma Hastanesi'nde doğan 250 yenidoğan bebek ile yapıldı. Annelere yapılacak işlemler ve amaç anlatılarak izin alındı. Hastane Etik Kurulu'ndan gerekli onay alındı.

Çalışmamızda 48 saatini doldurmuş, vajinal yolla veya sezeryan ile zamanında doğmuş, sorunsuz 250 yenidoğan bebekten B12 vitamini, homosistein düzeyi ve annelerinden vitamin B12 düzeyi bakıldı.

Homosistein düzeyine göre yenidoğan bebekler iki gruba ayrıldı. Olguların 132'sinde homosistein düzeyi $<10 \mu \mathrm{mol} / \mathrm{L}$ iken 118'inde $>10 \mu \mathrm{mol} / \mathrm{L}$ saptandl. Bu iki gruptan yararlanılarak B12 eşik değerinin belirlenmesi için ROC eğrisi çizildi. Yenidoğan bebeklerde B12 yeterliliği için eşik değeri $200 \mathrm{pg} / \mathrm{mL}$ olarak saptandı. Bu değer için duyarlılık \%75, özgüllük \%62 idi.

Homosistein için $20 \mu \mathrm{mol} / \mathrm{L}$ 'nin üzerindeki değerleri kobalamin sentez bozukluğu açısından anlamlı kabul edip, bu bebeklerden kan aminoasit analizi yapılarak sistatiyonin ve metiyonin seviyesi ölçüldü ve ayrıcı tanıda Şekil 1'deki diyagram (3) kullanıldı.

Annelerde B12 yeterliliği için eşik değer 300 pg/mL olarak alındı. Bu düzeyin belirlenme gerekçesi yazının ileri bölümlerinde ayrıca tartışıldı. Homosistein değeri erişkinde pek çok etmenden etkilendiği için bebeklerde olduğu gibi homosistein düzeyi üzerinden B12 eşik değerini belirleme yoluna gidilmedi (4).

B12 eksikliği açısından risk etmeni bulunan (vejetaryan, atrofik gastrit, antiasit kullanımı, kronik hastalık öyküsü) anne ve bebekleri çalışmaya alınmadı. Annelerin hepsinin gebelik süresince çoklu vitamin ve demir desteği almış olmasına dikkat edildi.
Hastanemizin bir devlet hastanesi olması ve bakmış olduğu hasta grubunun sosyoekonomik durumlarının iyi olmadığı bilinmektedir. Bu nedenle annenin sosyoekonomik durumu ve beslenmesi ayrıca değerlendirilmedi.

Venöz kandaki vitamin B12 düzeyi elektrokemiluminisans yöntemi ile (Abbott C2000i cihazı ile), homosistein düzeyi ise nefelometrik yöntem ile (BN2 Dadebehring cihazı ile) aynı gün içinde çalışıldı.

İstatistik

Verilerin analizinde SPSS (versiyon 10.0) istatistik programı kullanıldı. Verilerin normal dağılımı Kolmogorov Smirnov testi ile incelendi. Ölçümsel verilerin karşılaştııımasında bağımsız student $t$ testi kullanıldı. Yenidoğan bebeklerde eşik B12 değerinin belirlenmesi ROC eğrisi ile yapıldı.

\section{Bulgular}

Annelerin yaş aralığı 17 ile 42 yaş arasında olup ortalama $26,48 \pm 4,98$ yll idi.

Annelerin ortalama vitamin B12 düzeyi 209,69 $\pm 99,25$ $\mathrm{pg} / \mathrm{ml}$, bebeklerin vitamin B12 düzeyi 258,02 $\pm 141,00$ $\mathrm{pg} / \mathrm{mL}$ olarak ölçüldü. Belirlenen eşik değerlere göre annelerin \% 81,6'sında bebeklerin \% 42'sinde B12 eksikliği saptandı (Tablo 1).

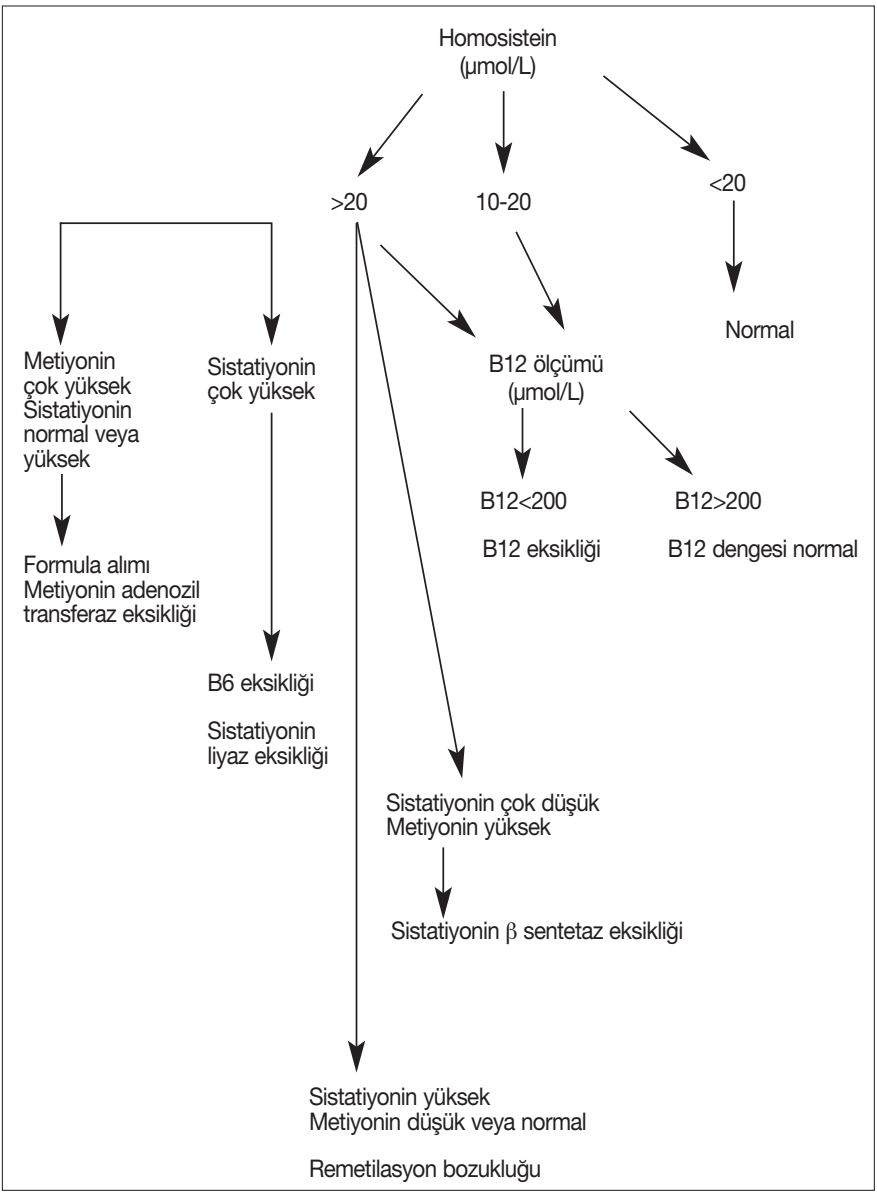

Şekil 1. Homosistein düzeyine göre ayrıcı tanı (3) 
Bebeklerin ortalama homosistein düzeyi ise $10,42 \pm 5,27$ $\mu \mathrm{mol} / \mathrm{L}$, di. Olguların \%52,8'inde $(n=132)$ homosistein düzeyi $\leq 10 \mu \mathrm{mol} / \mathrm{L}, \% 43,2^{\prime}$ inde $(\mathrm{n}=108) 10-20 \mu \mathrm{mol} / \mathrm{L}$, değer aralığında, \%4'ünde $(n=10) \geq 20 \mu \mathrm{mol} / \mathrm{L}^{\prime}$ dir. Homosistein düzeyi $\geq 20 \mu \mathrm{mol} / \mathrm{L}$, olan 10 olgunun hem kendisinde hem de annesinde ciddi B12 eksikliği saptandı. Bu 10 olguda kan aminoasit analizi yapılarak sistatiyonin ve metiyonin seviyesi normal bulunarak kobalamin metabolizması bozukluğu dışlandı.

B12 eksikliği bulunan olguların ortalama homosistein düzeyi $13,25 \pm 5,90 \mu \mathrm{mol} / \mathrm{L}$ iken B12 düzeyi normal olan olguların ortalama homosistein düzeyi $8,38 \pm 3,48 \mu \mathrm{mol} / \mathrm{L}$ bulundu. Aralarındaki fark $p<0,001$ düzeyinde istatistiksel olarak anlamlı idi (Tablo 2).

\section{Tartışma}

Dünya Sağlık Örgütü; normal yetişkinler için 1 mcg/gün, emziren kadınlar için $1,3 \mathrm{mcg} / \mathrm{gün}$, hamile kadınlar için $1,4 \mathrm{mcg} / \mathrm{gün}$ ve süt çocukları için $0,1 \mathrm{mcg} / \mathrm{gün}$ miktarında oral kobalamin alımını önerirken, birçok ülkede yetişkinlerde ortalama kobalamin alımının 1 mcg/gün'den daha az olduğunu tahmin etmektedir (5).

Yetişkinlerde normalde 2-3 mg B12 vitamini deposu vardır. Normal B12 vitamini deposuna sahip annelerin yenidoğan bebeği, sadece 25 mcg B12 vitamini deposuna sahipken, B12 vitamin eksikliği olan annelerin bebeğinde B12 vitamin deposu yaklaşık 3-5 mcg'dır. Kolostrum daha sonraki sütlerden çok daha fazla miktarda B12 vitamini içerir $(6,7)$. Anne sütündeki B12 vitamini miktarı, annedeki B12 vitamini depolarından daha çok B12 vitamininin diyetle alım miktarı ile ilişkilidir. Doğumda yenidoğan bebeğin B12 vitamin deposu eksik olsa da yaşamın en az birkaç haftası için yeterlidir $(7,8)$.

\begin{tabular}{|c|c|c|}
\hline \multicolumn{3}{|c|}{ Tablo 1. Anne ve bebekte vitamin B12 düzeyinin değerlendi- } \\
rilmesi \\
\hline & n & $\%$ \\
\hline Annenin B12 düzeyi & & \\
$<300 \mathrm{pg} / \mathrm{mL}$ & 204 & 81,6 \\
$>300 \mathrm{pg} / \mathrm{mL}$ & 46 & 18,4 \\
\hline Bebeğin B12 düzeyi & & \\
$<200 \mathrm{pg} / \mathrm{mL}$ & 105 & 42 \\
$<200 \mathrm{pg} / \mathrm{mL}$ & 145 & 58 \\
\hline Toplam 250 & 100 & \\
\hline
\end{tabular}

Tablo 2. B12 düzeyi $200 \mathrm{pg} / \mathrm{ml}$ 'nin altında olan olgular ile B12 düzeyi $200 \mathrm{pg} / \mathrm{mL}$ 'nin üzerinde olan olguların homosistein düzeylerinin karșılaștırılması

\begin{tabular}{|l|c|c|c|}
\hline & $<\mathbf{2 0 0} \mathbf{~ p g} / \mathbf{m L}$ & $\mathbf{2 0 0} \mathbf{~ p g} / \mathbf{m L}$ & $\mathbf{p}$ \\
\hline Homosistein düzeyi & $13,25 \pm 5,9$ & $8,38 \pm 3,48$ & $<0,001^{\star}$ \\
\hline
\end{tabular}

*Student $t$ test
B12 vitamin eksikliği ile ilgili literatürde daha önce bildirilen çalışmalar daha çok anemisi olan hasta çocuklarda yapılmıştır. Yakınması olmayan ve yenidoğan döneminde aileleri tarafından sağlıkı kabul edilen çocuklarda, B12 vitamin eksikliğinin sıklığı ile ilgili yeterli çalışma bulunmamaktadır.

Yaşamın ilk yıllarında plazma homosistein düzeyi serum kobalamin düzeyi ile güçlü ilişki gösterirken (9-12) folik asit düzeyi ile aralarındaki bağlantı zayıf $(9,11)$ veya hiç yoktur $(10,12)$. Illaveten yenidoğan ve süt çocuklarında ortalama homosistein düzeyi 6-9 $\mu \mathrm{mol} / \mathrm{L}$ olarak bildirilmiştir (9-12). Çalışmamızda homosistein düzeyi olguların \% 52,8'inde $(n=132)$ $\leq 10 \mathrm{mmol} / \mathrm{L}$; \%43,2'sinde $(\mathrm{n}=108) 10-20 \mathrm{mmol} / \mathrm{L}$; ve \%4'ünde $(n=10) \geq 20 \mathrm{mmol} / \mathrm{L}$ olarak bulundu. B12 eksikliği bulunan olguların ortalama homosistein düzeyi $13,25 \pm 5,90 \mathrm{mmol} / \mathrm{L}$ iken, B12 düzeyi normal olan olguların ortalama homosistein düzeyi $8,38 \pm 3,48 \mathrm{mmol} / \mathrm{L}$ bulundu. Aralarındaki fark $\mathrm{p}<0,001$ düzeyinde istatistiksel olarak anlamlı idi.

B12 eksikliğinin anemi olarak yansıması 100 pg/ml'nin altındaki vitamin B12 düzeylerinde olmaktadır. Lindenbaum ve ark.'ları (13) 1988 yllında vitamin B12 eksikliği bulunan hastalarda anemi veya makrositoz olmaksızın belirgin yüksek homosistein düzeyi bildirirlerken, Stabler ve ark.'ları (14) ise vitamin B12 eksikliği bulunan 78 olgunun 77 'sinde normalin üzerinde homosistein düzeyi varlığından söz etmişlerdir. Vitamin B12 eksikliği tanımı için eşik değerin ne olması gerektiği konusunda tam bir görüş birliği yoktur.

Anne-Mette Hvas ve ark.'ları (15) 125 pmol/L'nin (169 $\mathrm{pg} / \mathrm{ml}$ ) altındaki düzeyleri B12 eksikliği olarak tanımlarken, $125-250 \mathrm{pmol} / \mathrm{L}(169-338 \mathrm{pg} / \mathrm{mL})$ değer aralı̆ındaki B12 düzeylerinde homosistein-metiyonin döngüsünün iyi çalışmadığı (DNA sentezinin, metillenmenin iyi olmadığı), metilmalonikasidürinin oluşabildiği bir "gri bölge" olduğunu ifade etmişler, ancak 250 pmol/L'nin $(338 \mathrm{pg} / \mathrm{mL})$ üstündeki B12 değerlerinin yeterli görülebileceğini bildirmişlerdir. Bu nedenle fetal büyüme ve gelişmenin sağlıklı olması ve bu durumun emzirme döneminde de sürmesi için gebelerde ideal B12 düzeyi olarak laboratuvar eşik değerini (185 pg/mL) kabul etmek veya tanımlanan "gri bölgedeki" B12 düzeylerini almanın doğru olmadığı düşüncesindeyiz. $\mathrm{Bu}$ nedenle çalışmamızda annelerde B12 yeterliliğinden bahsedilebilecek bir düzey olan $300 \mathrm{pg} / \mathrm{mL}$ değeri eşik değer olarak alındı.

B12 yetersizliği hiperhomosisteinemi ve metilmalonikasidüri şekilde kendini gösterir. Bir çalışmada DNA hipometilasyonu, kromozom kırımaları, urasil depolanması ve mikronükleus oluşumunu en alt düzeye indirmek için B12 vitamini plazma düzeyinin $>300 \mathrm{pmol} / \mathrm{L}(406 \mathrm{pg} / \mathrm{mL}$ ) ve plazma homosistein düzeyinin $<7,5 \mu \mathrm{mol} / \mathrm{L}$ olması gerektiği bildirilmiştir (16). Karademir ve ark.'ları (17) sadece anne sütü alan bebeklerin özellikle ilk iki aya kadar olan dönemde B12 ile homosistein düzeyleri arasında bir ilişki olduğunu ve 200 pg/ml'nin üzerindeki B12 değerlerinde homosistein düzeylerinin 7,5 $\mathrm{mmol} / \mathrm{L}$ 'nin altında ve metilmalonik asit düzeylerinin normal değer aralığı içerisinde kaldığını göstermişlerdir. Bu nedenle biz de çallşmamızda homosistein düzeyine göre yenidoğan 
bebekleri iki gruba ayırdık. Olguların 132'sinde homosistein düzeyi $<10 \mu \mathrm{mol} / \mathrm{L}$ iken 118 'inde $>10 \mu \mathrm{mol} / \mathrm{L}$ saptand. Bu iki gruptan yararlanılarak yenidoğan bebeklerde B12 yeterliliği için için eșik değer $200 \mathrm{pg} / \mathrm{mL}$ olarak belirlendi.

B12 eksikliğini belirtmek için yapmış olduğumuz tanımlamada anneler için B12 alt sınıını 300 pg/ml, bebekler için $200 \mathrm{pg} / \mathrm{mL}$ olarak aldığımızda doğum sonrası dönemde annelerin \%81,6'sında ve bebeklerin \%41'inde B12 eksikliği saptandı. Çalışmamıza benzer şekilde Ackurt ve ark.'ları (18) İstanbul ve İzmir gibi Türkiye'nin iki gelişmiş şehrinde gebeliğin erken evrelerinde vitamin B12 eksikliği sıklığını \%48,8, ileri evrelerinde $\% 80,9$ ve doğum sonrası dönemde $\% 60$ olarak bildirmişlerdir. Koç ve ark.'larının (19) Urfa'da yapmış oldukları bir çalışmada ise B12 eşik değeri için laboratuvar eşik değeri (160 pg/mL) alınmasına rağmen annelerin \%72'sinde, bebeklerin \%41'inde B12 eksikliği saptamıșlardır. Söz konusu çalışmaların ve bizim çalışmamızın bir diğer ortak noktası annelerdeki yetersizliğin bebeklerden daha fazla oranda saptanmasıdır. Bu durum B12'nin plasenta yolu ile aktif olarak temin edilebilmesi ile açıklanabilir. Karademir ve ark.'ları (17) sadece anne sütü ile beslenen olguların yenidoğan dönemindeki B12 düzeylerinin ilk altı aylık dönemde değişmediğini, formula ile beslenmeleri durumunda B12 düzeyinin anlamlı olarak arttı̆̆ını göstermişlerdir. Bu durumda annesinde B12 yetersizliği olup, kendisinde eksiklik saptanmayan bebekler doğum sonrası dönemde sadece anne sütü almaları durumunda risk altındadır (19-21). Bu nedenle annenin B12 düzeyinin bebeğin B12 düzeyinden daha yüksek olması gerektiğini düşünmekteyiz.

B12 eksikliği açısından ciddi risk etmenleri taşımayan anne ve bebeklerde saptadığımız bu sorunun ailelerin sosyoekonomik seviyesinin düşük olması ile ilgili olduğunu düşünüyoruz. Bilindiği gibi, B12 vitamini için en iyi kaynak et, süt, balık, yumurta gibi hayvansal proteinlerdir. Bunların anne tarafından yeterince tüketilememesi, B12 vitamini eksikliği için önemli bir nedendir. Ancak çalışmamızda ailelerin sosyoekonomik düzeyleri ve beslenme durumunun sorgulanmaması bir eksiklik olarak görülebilir. Buna karşın hastanemize başvuran hasta grubunun sosyoekonomik durumlarının iyi olmadığı bilinmektedir.

Annelerin tümünün çoklu vitamin kullanmasına rağmen alınan bu kötü sonuçlar bizim gibi gelişmekte olan ülkelerde gebelik döneminde B12 desteğinin "kas içine uygulanarak karşılanmalı" tartışmasını da beraberinde getirmiştir. Sosyoekonomik düzeyi düşük olan annelerde B12 vitamin eksikliğinin yüksek oranda gelişebileceği ve bebeklerinde de bu yetersizliğin hem doğumda hem de anne sütü ile beslenme sırasında yüksek oranda görülebileceğinin çocuk doktorları tarafından bilinmesinin gerekliliği ortadadır.

\section{Kaynaklar}

1. Mittal VS, Agarwal KN. Observations on nutritional megaloblastic anemias in early childhood. Indian J Med Res 1969; 57: 730-8. Abstract

2. Allen LH. Vitamin B12 metabolism and status during pregnancy, lactation and infancy. In: Allen L H, King J, Lonnerdal B (eds). Nutrient regulation during pregnancy, lactation and infant growth. New York: Plenum Pres, 1994: 173-86.
3. Refsum H, Grindflek AW, Ueland PM, et al. Screening for serum total homocysteine in newborn children. Clin Chem 2004; 50: 1769-84. Abstract / Eull Tex / PDA

4. Neki NS. Hyperhomocysteinemia-an independent risk factor for cardiovascular diseases. JIACM 2003; 4: 55-60.

5. Whiteheat VM, Rosenblatt DS, Cooper BA. Megaloblastic anemia. In: Nathan DG, Orkin SH (eds). Nathan and Oski's Hematology of Infancy and Chilhood. 15th ed. Philadelphia: WB Saunders Co, 1998: 385-415.

6. Adkins $Y$, Lönnerdal B. Mechanisms of vitamin B12 absorption in breast-fed infants. J Pediatr Gastroenterol Nutr 2002; 35: $192-8$. Full Tex

7. Rosenblatt DS, Whitehead VM. Cobalamin and folate deficiency: acquired and hereditary disorders in children. Semin Hematol 1999; 36: 19-34. Abstract

8. Michaud JL, Lemieux B, Ogier H, Lambert MA. Nutritional vitamin B12 deficiency: two cases detected by routine newborn urinary screening. Eur J Pediatr 1992; 151: 218-20. Aabstract

9. Guerra-Shinohar EM, Paiva AA, Rondo PH, Yamasaki K, Terzi CA, D'Almeida V. Relationship between total homocysteine and folate levels in pregnant women and their newborn babies according to maternal serum levels of vitamin B12. BJOG 2002; 109: 784-91. Abstract/[Full Text]/PDA

10. Bjorke-Monsen AL, Ueland PM, Vollset SE, et al. Determinants of cobalamin status in newborns. Pediatrics 2001; 108: 624-30. Abstract/PDF

11. Minet JC, Bisse E, Aebischer CP, Beil A, Wieland H, Lütschg J. Assessment of vitamin B-12, folate, and vitamin B-6 status and relation to sulfur amino acid metabolism in neonates. Am J Clin Nutr 2000; 72: 751-7. Abstrac / Full Tex/ PDA

12. Molloy AM, Mills JL, McPartlin J, Kirke PN, Scott JM, Daly S.Maternal and fetal plasma homocysteine concentrations at birth: the influence of folate, vitamin B12, and the 5, 10-methylenetetrahydrofolate reductase $677 \mathrm{C} \rightarrow$ T variant. Am J Obstet Gynecol 2002; 186: 499-503. [Abstract / Eull Tex] / PDA

13. Lindenbaum J, Healton EB, Savage DG, et al. Neuropsychiatric disorders caused by cobalamin deficiency in the absence of anemia or macrocytosis. N Engl J Med 1988; 318: 1720-8.

14. Stabler SP, Marcell PD, Podell ER, Allen RH, Savage DG, Lindenbaum J. Elevation of total homocysteine in the serum of patients with cobalamin or folate deficiency detected by capillary gas chromatography-mass spectrometry. J Clin Invest 1988; 81: 466-74. Abstract/[Full Text/ (PDF)

15. Hvas AM, Nexo E. Diagnosis and treatment of vitamin B12 deficiency-an update. Haematologica 2006; 91: 1506-12. Abstract / PDH

16. Fenech $\mathrm{M}$. The role of folic acid and vitamin B12 in genomic stability of human cells. Mutat Res 2001; 475: 57-67. Abstrac/ PDA

17. Karademir F, Suleymanoglu S, Ersen A, et al. Vitamin B12, folate, homocysteine and urinary methylmalonic acid levels in infants. J Int Med Res 2007; 35: 384-8. Abstract/PDF

18. Ackurt $F$, Wetherilt $H$, Loker $M$, Hacibekiroğlu M. Biochemical assessment of nutritional status in pre and post-natal Turkish women and outcome of pregnancy. Eur J Clin Nutr 1995; 49: 613-22. Abstract

19. Koc A, Kocyigit A, Soran M, et al. High frequency of maternal vitamin B12 deficiency as an important cause of infantile vitamin B12 deficiency in Șanlıurfa province of Turkey. Eur J Nutr 2006; 45: 291-7. (Abstrac) / PDH

20. Specker BL, Black A, Allen L, Morrow F. Vitamin B-12: low milk concentrations are related to low serum concentrations in vegetarian women and to methylmalonic aciduria in their infants. Am J Clin Nutr 1990; 52: 1073-6. Abstrac/ PDA

21. Casterlina JE, Allen LH, Ruel MT. Vitamin B-12 deficiency is very prevalent in lactating Guatemalan women and their infants at three months postpartum. J Nutr 1997; 127: 1966-72. Abstrac / Full Tex / PDF 